\title{
An Easy, Quick and Cost Effective Method of High Quality DNA Extraction from Mungbean [Vigna radiata (L.) Wilczek] Without Liquid Nitrogen
}

\author{
Supriya Ambawat ${ }^{1,2}$, Ram Kumar ${ }^{1 *}$, Subaran Singh ${ }^{1,2}$ and Rajesh Yadav ${ }^{1}$ \\ ${ }^{1}$ Department of Genetics and Plant Breeding, Chaudhary Charan Singh Haryana Agricultural \\ University, Hisar 125004, Haryana, India \\ ${ }^{2}$ Department of Agriculture Sciences and Research, SGV University, \\ Jaipur-302 017, Rajasthan, India \\ *Corresponding author
}

\section{A B S T R A C T}

\begin{tabular}{|l|}
\hline Ke y w or d s \\
Green gram, DNA \\
extraction, \\
Standardization, \\
Phenols, Liquid \\
nitrogen.
\end{tabular}

Green gram is a widely cultivated pulse crop rich in protein, essential amino acids and vitamin-B. The quality and quantity of DNA are very important for amplification by PCR. Although quantity of DNA required per reaction in PCR is very low, quality is very crucial. Also, to carry out large number of PCR reactions for genotyping, a good amount of DNA is required. Presence of contaminants like phenols makes it difficult to get good quality DNA from mungbean. Thus, the present study was undertaken to obtain high quality and pure DNA in mungbean. The method involves extraction of DNA using a buffer (pH 8.0) containing 100mM Tris, 50mM EDTA, 500mM NaCl, 2\%PVP, $2 \%$ CTAB and $0.2 \% \beta$-mercaptoethanol followed by purification of DNA with chloroform and isoamyl alcohol and finally precipitation of DNA by sodium acetate and isopropanol. The method is suitable for extraction of DNA from small to large number of plant samples. DNA obtained through this protocol is of high quality and free of phenols which gave amplifying products in the PCR. Here, we developed a simple, fast, efficient, economical method for isolation of DNA from green gram without liquid nitrogen which could be stored for longer duration and does not require expensive chemicals such as proteinase $\mathrm{K}$, liquid nitrogen etc.

\section{Introduction}

Green gram (Vigna radiata (L.) Wilczek) or mungbean is a self-pollinated widely cultivated leguminous crop in India. It belongs to the family Leguminaceae and subgenus Ceratotropis with diploid chromosome number $(2 \mathrm{n}=2 \mathrm{x}=22)$ (Kang et al., 2014). It is mainly grown in tropical Africa and Asia and several Vigna species have been domesticated in Asia. It is an important source of protein for the human population and soil health as it fixes atmospheric nitrogen.
High protein, easy digestibility and low flatulence make it widely acceptable to the people world over. The annual world production area of mungbean is about 5.5 million hectare of which about $90 \%$ is in Asia (Lambrides and Godwin, 2007). India is the largest producer of mungbean and occupies an area of 34.4 lakh hectares with a production of 1.60 million tonnes and productivity of $568 \mathrm{~kg} / \mathrm{ha}$ (2015-2016). Genus Vigna have high amount of polyphenol, orthohydroxyphenols and polysaccharides. 
These are powerful oxidizing agents to interfere with genomic DNA which can further inhibit the PCR amplification. Good quality and quantity of DNA is a prerequisite for various experiments of molecular biology. DNA purity is very important for amplification by PCR and to get clear and reproducible results.

For marker assisted selection, lesser number of PCR reactions are carried out and hence less amount of DNA is needed which further doesn't require long time storage (McCarthy and Berger, 2002). But, in case of QTL mapping or population studies of $\mathrm{F}_{2}$, RILs etc. larger number of $\mathrm{PCR}$ reactions are to be performed and thus more amount of purified DNA is required as well as it need to be stored for a longer duration. Thus, an efficient, fast and easy method for DNA extraction is extremely required. Among the most commonly used basic plant DNA extraction protocols include Murray and Thompson (1980), Dellaporta et al., (1983), Saghai Maroof et al., (1984) and Doyle and Doyle (1990) along with many others that are modifications of the components of these protocols to suit a particular tissue type or downscaling them for miniprep. Most of these protocols are time consuming, comparatively expensive and require liquid nitrogen for grinding of samples (Sharma et al., 2003; Allen et al., 2006). Liquid nitrogen is usually expensive and difficult to procure in remote locations, a method not requiring its use would be more helpful. In addition to these basic protocols, several DNA isolation kits based on either anion exchange chromatography or silica gel membranes are available commercially. Though these kits are convenient and usually safe as they don't use hazardous reagents but their availability to certain developing countries and high cost can be limiting, especially when handing a large number of samples and considering experiments with limited financial resources
Furthermore, in some instances, commercial kits have produced low DNA yields and variable quality (Chen et al., 2006; Thomas and Dominic, 2015).

Although various protocols are available for DNA isolation in wheat (Stein et al., 2001; Dellaporta et al., 1983; McCarthy and Berger, 2002), Cicer (Chakraborti et al., 2006), nodules of legumes (Krasova-Wade and Neyra, 2007) and in other plant species (Lange et al., 1998). All of these protocols either involve elaborative and time consuming steps and use of expensive chemicals such as proteinase $\mathrm{K}$, liquid nitrogen etc. On the other hand, some methods involve use of specific equipment designed especially for DNA isolation while others may be suitable for isolation of DNA from seed material and not for leaf tissue (McCarthy and Berger, 2002). In case of food legumes, presence of phenols and other contaminants offer difficulty in pipetting DNA and make DNA unamplifiable in PCR reaction by inhibiting Taq DNA polymerase. Therefore, a protocol is required which can provide high quality and pure DNA in green gram. Here, we describe a DNA extraction protocol suited for isolation of relatively pure DNA in sufficient amount from green gram that can be stored for a longer duration and gave amplified products for PCR reactions. The method is easy, rapid involving no liquid nitrogen and other hazardous and expensive chemicals like phenol, proteinase $\mathrm{K}$ etc.

\section{Materials and Methods}

\section{Plant material}

A total of 34 genotypes of mungbean were used for this study which included varieties from germplasm collection released from CCS HAU, Hisar, PAU, Ludhiana, Indian Institute of Pulses Research (Kanpur), some advanced breeding lines and exotic 
germplasm lines (Table 1). Plants were grown in field conditions using standard agronomic practices. Young and healthy leaves of two week old seedlings were collected in ice box for DNA isolation and stored at $-20^{\circ} \mathrm{C}$ until use.

\section{Solutions and reagents}

CTAB Buffer: The extraction buffer consisted of $100 \mathrm{mM}$ Tris- $\mathrm{HCl}(\mathrm{pH} 8.0), 50 \mathrm{mM}$ EDTA (pH 8.0), $500 \mathrm{mM} \mathrm{NaCl}, 2 \%$ (w/v) PVP$40,000,2 \%$ CTAB. Just prior to use, add $0.2 \% \quad(\mathrm{v} / \mathrm{v}) \quad \beta$-Mercaptoethanol to the extraction buffer and warm at $65^{\circ} \mathrm{C}$ in a water bath.

Chloroform: isoamyl alcohol (24:1) mixture

$3 \mathrm{M}$ sodium acetate $(\mathrm{pH} 5.8)$

Isopropanol

$70 \%$ ethanol

TE buffer (10 mM Tris-HCl, 1 mM EDTA)

RNase A (10mg / ml)

\section{DNA extraction protocol}

3-4 young and healthy leaves were ground in $1 \mathrm{ml}$ CTAB extraction buffer without liquid nitrogen using a pestle and mortar. The mixture was transferred into eppendorf tubes with a spatula and $500 \mu \mathrm{l}$ of extraction buffer was added further. It was incubated for $1 \mathrm{hr}$ with occasional mixing by inversion in a water bath maintained at $65^{\circ} \mathrm{C}$. After incubation, the tubes were centrifuged at $10,000 \mathrm{rpm}$ for $10 \mathrm{~min}$ and the supernatant was collected into new eppendorf tubes. 500 $\mu \mathrm{l}$ of chloroform: isoamyl alcohol (24:1) was added and mixed gently by inverting for 5 min followed by centrifugation at $10,000 \mathrm{rpm}$ for $15 \mathrm{~min}$ at $4^{\circ} \mathrm{C}$. The aqueous phase having
DNA was carefully transferred to a fresh centrifuge tube avoiding the interphase. Again, equal volume of CI (24:1) was added to the tube and mixed gently followed by centrifugation. This step was repeated twice. DNA was precipitated by adding 1/10 volume of $3 \mathrm{M}$ sodium acetate and equal volume of ice-cold isopropanol followed by gentle mixing and kept at $4{ }^{\circ} \mathrm{C}$ overnight. Next day, the samples were centrifuged at 10,000 rpm for $10 \mathrm{~min}$ and the resultant supernatant was discarded gently and the DNA pellet was washed with $70 \%$ ethanol and centrifuged at $10,000 \mathrm{rpm}$ for $10 \mathrm{~min}$. This step was repeated twice. The pellet was air dried and dissolved in $150 \mu \mathrm{TE}$ buffer and stored at $20^{\circ} \mathrm{C}$. $3 \mu \mathrm{l}$ RNase A (10 mg/ml) was added to the tubes and were kept in water bath at $37^{\circ} \mathrm{C}$ for $1 \mathrm{hr}$.

\section{DNA quantification}

The yield of extracted DNA was analyzed on UV-VIS spectrophotometer by reading absorbance at $260 \mathrm{~nm}$ and purity was checked by taking the ratio at 260/280 $\mathrm{nm}$. The isolated DNA was also analyzed on agarose gel electrophoresis. For gel preparation, $0.8 \mathrm{~g}$ of agarose was weighed and added to $100 \mathrm{ml}$ of $1 \mathrm{X}$ TBE buffer to get final concentration of $0.8 \%$. Agarose was dissolved properly by boiling in microwave oven and cooled to about $55^{\circ} \mathrm{C}$. Then, $5 \mu 1$ of ethidium bromide $(10 \mathrm{mg} / \mathrm{ml})$ was added to it and after mixing completely poured into the gel casting tray carefully without formation of any air bubbles and left for solidification for 20-30 min. Then, $2 \mu 1$ DNA sample and $3 \mu 1$ of $6 \mathrm{X}$ loading dye were mixed on a parafilm and loaded into the wells of the gel. $\lambda$ DNA of known quantity having concentration of viz.100 ng was also loaded to quantify the DNA samples. The gel was run at $80 \mathrm{~V}$, till the tracking dye migrated to the bottom of the gel. The DNA samples were visualized using a UV gel documentation system (Benchtop Lab 
Equipment) and photographed and documented.

\section{PCR assay}

Amplification reactions were carried out in a volume of $20 \mu \mathrm{l}$ reaction mixture containing $1 \mathrm{U}$ Taq DNA polymerase (G Biosciences), 1X PCR buffer (10 mM Tris $\mathrm{HCl}(\mathrm{pH} 8.3), 50$ $\mathrm{mM} \mathrm{KCl}, 1.5 \mathrm{mM} \mathrm{MgCl}_{2}$ ), $200 \mu \mathrm{M}$ dNTP mix, $0.5 \mu \mathrm{M}$ forward and reverse primers, $5 \%$ DMSO, 50 ng of DNA. PCR cycles consisted of initial denaturation at $94^{\circ} \mathrm{C}$ for $3 \mathrm{~min}$ followed by 35 cycles of denaturation at $94^{\circ} \mathrm{C}$ for $1 \mathrm{~min}$, annealing at $53^{\circ} \mathrm{C}$ for $50 \mathrm{~s}$, extension at $72^{\circ} \mathrm{C}$ for $2 \mathrm{~min}$ and a final extension at $72^{\circ} \mathrm{C}$ for $7 \mathrm{~min}$. The amplified products were analyzed on $3.5 \%$ agarose gel and visualized under UV transilluminator and photographed using gel documentation system.

\section{Results and Discussion}

The isolation of high quality DNA is a crucial step in the field of plant molecular biology. Most DNA extraction methods are timeconsuming, involve multiple steps, expensive chemicals and enzymes and use hazardous procedures of grinding plant tissue in liquid nitrogen $\left(\mathrm{N}_{2}\right)$ to break down the cell wall of plants (Sharma et al., 2003) or freeze-drying (lyophilization) (Sperisen et al., 2000). Procurement and storage of liquid nitrogen may be difficult for many laboratories and handling of the same is also difficult. Thus, any method which doesn't need liquid nitrogen can be more helpful. The need of liquid nitrogen during grinding step has been eliminated by many workers using soft tissues such as flower petals or young leaves (Khan et al., 2004), cold and heat shock treatments, (Biswas and Biswas, 2011) alcohol fixation (Sharma et al., 2003; Sharma et al., 2010). (Duan et al., 2015; Ibemhal et al., 2015). Here, we developed an easy, fast, inexpensive method to isolate high quality genomic DNA from mungbean eliminating the use of hazardous chemical phenol and expensive reagents like proteinase $\mathrm{K}$ and liquid nitrogen. The yield of extracted DNA using this method ranged from 100.5-320.2 $\mathrm{ng} / \mu \mathrm{l}$ and the ratio of $\mathrm{A}_{260 / 280}$ varied from 1.78 to 2.00 indicating good quality DNA which is free from protein contamination (Table 2). Similar kind of yield and quality of DNA was also reported in other protocols (Henry, 1997; Sharma et al., 2003, Sharma et al., 2010). A ratio of absorbance $260 / 280$ is used to assess the purity of nucleic acid and its accepted range is mainly $\sim 1.8$.

In addition, on analysis on agarose gel electrophoresis, it showed no visible DNA degradation or RNA contamination indicating good quality and quantity of extracted genomic DNA (Fig. 1). The good quality of DNA extracted in our study is comparable to various other studies where it was reported that good quality DNA can be isolated without using liquid nitrogen (Chandra and Tewari, 2009; Sharma et al., 2010; Ferdous et al., 2012).

For DNA extraction, the ground tissue is transferred to an extraction buffer which contains detergent to disrupt the membranes. Cetyltrimethyl ammonium bromide (CTAB) is commonly used for plant DNA extraction to disrupt the rigid cell wall. The extraction buffer also contains a reducing agent $(\beta$ mercaptoethanol) and a chelating agent (ethylenediamine tetraacetic acid, EDTA) which chelates the magnesium ions required for DNase activity. Thus, it inactivate nucleases that are released from the plant cell and causes serious degradation of the genomic DNA. Phenol extraction can be used to remove any traces of proteins and the genomic DNA can be precipitated using either ethanol or isopropanol. Precipitated DNA can be hooked out of the solution or collected by centrifugation. In the present study, the extracted DNA was free of phenols as the pellet obtained was clean and white to 
pale yellow in colour while usually in pulses brown colored DNA pellet is obtained due to presence of phenols and the quality of DNA isolated was comparable to other such recent studies (Laxmi prasanna et al., 2013; Healey et al., 2014; Rawat et al., 2016; Sajib et al., 2017). Moreover, here we used young and tender leaves as they contain less phenol as compared to mature leaves which contain more phenol content and the DNA obtained is generally brown in color. Thus, young and tender leaves of approximately two week old seedlings are more ideal for DNA extraction in green gram. Phenolic compounds may also be released on disruption of plant tissues and these may interfere with subsequent uses of the DNA such as it may inhibit PCR. Contrary to it, the method described here is very efficient as the DNA obtained through this protocol was relatively pure which gave amplifying products in the PCR (Fig. 2).
Horne et al., (2004) reported that some contaminants such as phenols which inhibit PCR could not be removed with chloroform extraction, so to remove phenolic compounds during extraction, $2 \%$ polyvinyl pyrolidone (PVP) and 2\% $\beta$-mercaptoethanol was added to the extraction buffer. $\beta$-mercaptoethanol is a reducing agent which helps in denaturing proteins by breaking the disulfide bonds between the cysteine residues and for removing the tannins and polyphenols present in the crude extract. In addition to saturated phenol, enzyme proteinase $\mathrm{K}$ is also used to remove proteins which however is again denatured by phenol via phenol chloroform extraction and moreover it is costly. Further in the present study to remove proteins, instead of using phenol/PCI (25:24:1), only CI (24:1) was used to get good quality DNA thus reducing cost as well as health risks associated with use of phenol.

Table.1 List of 34 genotypes of mungbean used in the study

\begin{tabular}{|c|c|c|c|c|c|}
\hline $\begin{array}{l}\text { S. } \\
\text { No. }\end{array}$ & Genotype & Source & $\begin{array}{l}\text { S. } \\
\text { No. }\end{array}$ & Genotype & Source \\
\hline 1. & ML776 & PAU, Ludhiana & 18. & MH1142 & CCSHAU, Hisar \\
\hline 2. & GP111 & Germplasm line, Hisar & 19. & Kopergaon & Akola, Maharashtra \\
\hline 3. & MH421 & CCSHAU, Hisar & 20. & SMH 99-1 & CCSHAU, Hisar \\
\hline 4. & Pusa 1431 & IARI, New Delhi & 21. & BDYR-1 & Exotic line \\
\hline 5. & MH 534 & CCSHAU, Hisar & 22. & 2KM138 & $\begin{array}{l}\text { Coordinated } \\
\text { program }\end{array}$ \\
\hline 6. & MH 565 & CCSHAU, Hisar & 23. & PM 827 & PAU, Ludhiana \\
\hline 7. & Muskan & CCSHAU, Hisar & 24. & ML 2037 & IIPR, Kanpur \\
\hline 8. & Pusa 1532 & IARI, New Delhi & 25. & LGG 460 & Guntur, AP \\
\hline 9. & IPM 9901-8 & IIPR, Kanpur & 26. & Pusa 1531 & IARI, New Delhi \\
\hline 10. & Pusa 1542 & IARI, New Delhi & 27. & MH 98-1 & CCSHAU, Hisar \\
\hline 11. & Pusa 1501 & IARI, New Delhi & 28. & Pusa 871 & IARI, New Delhi \\
\hline 12. & Pusa 1502 & IARI, New Delhi & 29. & 2KM 112 & IARI, New Delhi \\
\hline 13. & Asha & CCSHAU, Hisar & 30. & Pusa 1142 & IARI, New Delhi \\
\hline 14. & SML668 & PAU, Ludhiana & 31. & MH 1157 & CCSHAU, Hisar \\
\hline 15. & МH318 & CCSHAU, Hisar & 32. & MH 731 & CCSHAU, Hisar \\
\hline 16. & Satya & CCSHAU, Hisar & 33. & MH 810 & CCSHAU, Hisar \\
\hline 17. & Basanti & CCSHAU, Hisar & 34. & Pusa 9072 & IARI, New Delhi \\
\hline
\end{tabular}


Table.2 Concentration and $\mathrm{A}_{260} / \mathrm{A}_{280}$ ratio of extracted DNA from young leaves of 34 genotypes of mungbean

\begin{tabular}{|c|c|c|c|c|c|c|c|}
\hline $\begin{array}{l}\text { S. } \\
\text { No. }\end{array}$ & Genotype & $\begin{array}{l}\text { DNA Conc. } \\
(\mathrm{ng} / \mu \mathrm{l})\end{array}$ & $A_{260 / 280}$ & $\begin{array}{l}\text { S. } \\
\text { No. }\end{array}$ & Genotype & $\begin{array}{l}\text { DNA Conc. } \\
(\mathrm{ng} / \mu \mathrm{l})\end{array}$ & $\mathbf{A}_{260 / 280}$ \\
\hline 1. & ML776 & 152.4 & 1.85 & 18. & MH1142 & 300.4 & 1.83 \\
\hline 2. & GP111 & 154.3 & 1.78 & 19. & Kopergaon & 200.6 & 1.78 \\
\hline 3. & MH421 & 200.1 & 1.90 & 20. & SMH 99-1 & 210.5 & 1.89 \\
\hline 4. & Pusa 1431 & 140.3 & 1.83 & 21. & BDYR-1 & 320.2 & 1.84 \\
\hline 5. & MH 534 & 130.4 & 1.80 & 22. & 2KM138 & 250.6 & 1.83 \\
\hline 6. & MH 565 & 128.2 & 2.00 & 23. & PM 827 & 220.3 & 1.79 \\
\hline 7. & Muskan & 125.1 & 1.86 & 24. & ML 2037 & 206.4 & 1.80 \\
\hline 8. & Pusa 1532 & 135.3 & 1.79 & 25. & LGG 460 & 270.2 & 1.86 \\
\hline 9. & IPM 9901-8 & 130.2 & 1.80 & 26. & Pusa 1531 & 300.7 & 1.78 \\
\hline 10. & Pusa 1542 & 127.4 & 1.83 & 27. & MH 98-1 & 200.2 & 1.92 \\
\hline 11. & Pusa 1501 & 150.2 & 1.78 & 28. & Pusa 871 & 150.4 & 1.80 \\
\hline 12. & Pusa 1502 & 130.4 & 1.88 & 29. & 2KM 112 & 100.5 & 1.91 \\
\hline 13. & Asha & 135.6 & 1.78 & 30. & Pusa 1142 & 230.1 & 1.80 \\
\hline 14. & SML668 & 129.3 & 1.86 & 31. & MH 1157 & 100.6 & 1.98 \\
\hline 15. & MH318 & 170.2 & 1.79 & 32. & MH 731 & 150.4 & 1.87 \\
\hline 16. & Satya & 160.4 & 1.80 & 33. & MH 810 & 120.3 & 1.82 \\
\hline 17. & Basanti & 190.2 & 1.81 & 34. & Pusa 9072 & 130.2 & 1.88 \\
\hline
\end{tabular}

Fig.1 Analysis of genomic DNA extracted from various genotypes of mungbean on $0.8 \%$ agarose. Lane M- DNA, Lane 1-34 -various genotypes of mungbean

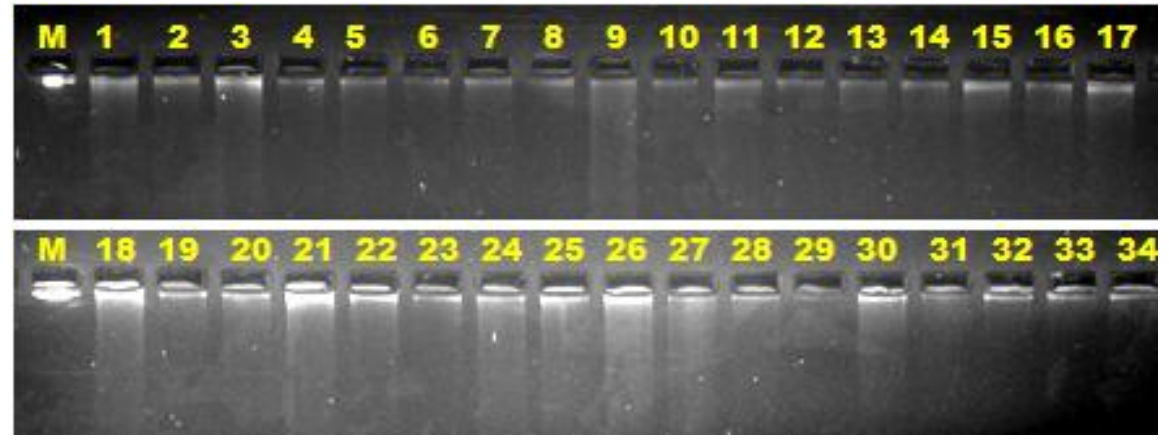

Fig.2 PCR amplification with extracted DNA using SSR marker on 3.5\% agarose gel. Lane M50 bp ladder, Lane 1-6 - DNA of various mungbean genotypes used for PCR

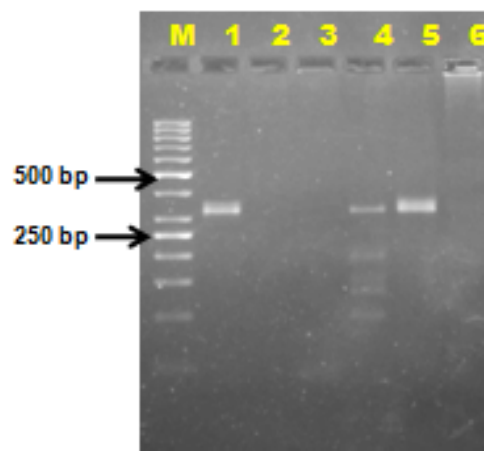


A salt such as sodium chloride is used in extraction buffer which aids in precipitation by neutralizing the negative charges on the DNA so that the molecules can come together. At lower $\mathrm{NaCl}$ concentrations $(<0.4$ $\mathrm{M})$, DNA and CTAB form an insoluble complex (Murray and Thompson, 1980) which is separated from the residual soluble proteins, polysaccharides and other molecules by centrifugation. Similar low salt/CTAB strategies have been used to collect DNA in mungbean (Vigna radiata) (Murray and Thompson, 1980), orpine (Sedum telephium) (Barnwell et al., 1998), cotton (Gossypium spp.) (Zhang and Stewart, 2000) and rice (Vibhuti et al., 2015). Further, chloroform is required to remove major protein, phenolics and cell debris contaminates. The DNA is precipitated using equal volume of isopropanol and diluting the nucleic acid with a monovalent salt and mixing gently and the pellet is collected by centrifugation. The salts are removed by washing with $70 \%$ alcohol.

The most commonly used salts include sodium acetate $\mathrm{pH} 5.2$ (final volume $0.3 \mathrm{M}$ ), sodium chloride (final concentration $0.2 \mathrm{M}$ ), ammonium acetate $(2-2.5 \mathrm{M})$, lithium chloride $(0.8 \mathrm{M})$ and potassium chloride. Ethanol (twice the volume) or isopropanol (equal volume) are the standard alcohols used for nucleic acid precipitation. It is important that DNA is not sheared, for this reason the DNA should not be vortexed or pipetted repeatedly using a fine tipped pipette and all manipulations should be as gentle as possible. Further, keeping the reactions cold during isolation steps can minimize their effects and improve the quality of DNA. After RNAase treatment, people generally follow purification steps by performing CI extractions which can reduce DNA quantity. Here, no purification steps were carried out further after RNAse treatment which saves time and good quality DNA was also observed which was directly used for PCR amplification and good intensity of bands was observed.

In summary, here we describe a simple, safe, fast and cost efficient CTAB DNA extraction protocol without liquid nitrogen which provides high quality pure DNA from mungbean which generally contain high concentration of phenolic compounds. Thus, it gives sufficiently pure DNA, which may be suitable for carrying out large scale marker analysis and genotyping reducing time and cost and moreover the same may be preserved for a longer duration.

\section{Acknowledgements}

We sincerely acknowledge Dr. RK Sheoran and Dr. Ram Avtar, Oilseeds Section, Department of Genetics and Plant breeding, CCS HAU, Hisar (Haryana) for providing lab facilities to carry out the research work. This work was financially supported by the Indian Council of Agricultural Research (ICAR), India, under Emeritus Scientist Scheme (grant number 5390-C (b) PB-177-ICAR).

\section{References}

Allen, G.C., Vergara, M.A.F., Krasnyanski, S., Kumar, S. and Thompson, W.F. 2006. A modified protocol for rapid DNA isolation from plant tissue using cetyltrimethyl ammonium bromide. Nature protocols. 1: 2320-2325.

Biswas, K., and Biswas, R. 2011. A modified method to isolate genomic DNA from plants without liquid nitrogen Current Sci. 100:1622-1624.

Chakraborti, D., Sarkar, A., Gupta, S. and Das, S. 2006. Small and large scale genomic DNA isolation protocol for chickpea (Cicer arietinum L.), suitable for molecular marker and transgenic analyses. Afr. J. Biotechnol. 5: 585-589.

Chandra, A., and Tewari, S. 2007. Isoaltion of 
genomic DNA from Stylo species without liquid nitrogen suitable for RAPD and STS analysis. Cytologia 72: 287.

Chen, W.Y., Cui, H.R., Bao, J.S., Zhou, X.S. and Shu, Q.Y. 2006. A simplified rice DNA extraction protocol for PCR analysis. Rice Sci. 13(1): 67-70.

Dellaporta, S.L., Wood, J. and Hicks, J. 1983. A plant DNA mini preparation version 2. Plant Mol. Bio. Rep. 1: 19-22.

Doyle, J.J., and Doyle, J.L. 1990. Isolation of plant DNA from fresh tissue. Focus 12:3-15.

Duan, Y.B., Zhao, F.L., Chen, H.D., Li, H., Ni, D.H., Wei, P.C., Sheng, W., Teng, J.T., Zhang, A.M. and Xue, J.P. 2015. A simplified genomic DNA extraction protocol for pre-germination genotyping in rice. Genet. Mol. Res. 14(2): 63696375.

Ferdous, J., Hanafi, M.M., Rafii, M.Y. and Muhammad, K. 2012. A quick DNA extraction protocol: without liquid nitrogen in ambient temperature. Afr. $J$. Biotech. 11:6956-6964.

Healey, A., Furtado, A., Cooper, T. and Henry, R.J. 2014. Protocol: a simple method for extracting next-generation sequencing quality genomic DNA from recalcitrant plant species. Plant Methods 10:21.

Henry, R.J., 1997. Practical Applications of Plant Molecular Biology, $1^{\text {st }}$ ed, Chapman and Hall, London.

Horne, E.C., Kumpatla, S.P., Patterson, K.A., Gupta, M. and Thompson, S.A. 2004. Improved high-throughput sunflower and cotton genomic DNA extraction and PCR fidelity. Plant Mol. Biol. Rep. 22: $83 a-83 i$.

Ibemhal, D.A., Majumder, P.B., Imotomba, R.K. and Laishram, J.M. 2015. Genomic DNA extraction from the black scented rice (Chakhao). Indian J. Plant Sci. 4 (1) 34-37.
Kang, Y.J., Kim, S.K., Kim, M.Y. et al., 2014. Genome sequence of mungbean and insights into evolution within Vigna species. Nature Communications 5:5443 doi: 10.1038/ncomms6443.

Khan, I.A., Awan, F.S., Ahmad, A. and Khan, A.A. 2004. A modified mini-prep method for economical and rapid extraction of genomic DNA in plants. Plant Mol. Biol. Rep. 22: 89a-89e.

Krasova-Wade, T., and Neyra, M. 2007. Optimization of DNA isolation from legume nodules. Letters in Appl. Micro. 45: 95-99.

Lambrides, C.J., and Godwin, I. 2007. Mungbean In: Genome Mapping and Molecular Breeding in Plants. Volume 3: Pulses, sugar and tuber crops (Kole, C. eds), Springer, Berlin and Heidelberg, pp. 69-90.

Lange, D.A., Penuela, S., Denny, R.L., Mudge, J., et al., 1998. A plant DNA isolation protocol suitable for polymerase chain reaction based marker assisted breeding. Crop Sci. 38: 217220.

Laxmi-prasanna, B., Rao, P.J.M., Srividhya, A., Yamini, K.N., and Murthy, K.G.K. 2013. Standardization of DNA extraction protocol in greengram (Vigna radiata (L.) Wilczek). Int. J.Appl. Pharma Tech. 4(4): 86-91.

McCarthy, P.L., and Berger, P.H. 2002. Rapid identification of transformed wheat using a half-seed PCR assay prior to germination. Biotechniques 32: 560564.

Murray, M.G., and Thompson, W.F. 1980. Rapid isolation of high molecular weight plant DNA. Nucl. Acid Res. 8: 19: 4321-4325.

Rawat, S., Joshi, G., Annapurna, D., Arunkumar, A.N., and Karaba, N.N. 2016. Standardization of DNA Extraction Method from Mature Dried Leaves and ISSR-PCR Conditions for 
Melia dubia Cav. -A Fast growing multipurpose tree species. American J. Plant Sci. 7: 437-445.

Saghai-Marrof, M.A., Soliman, K.M., Jorgensen, R.A. and Allard, R.W. 1984. Ribosomal DNA spacer-length polymorphism in barley: Mendelian inheritance, chromosomal location, and population dynamics. Proc. Natl. Acad. Sci. USA 81: 8014-8018.

Sajib, A.A., Bhuiya, M.A.I. and Huque, R. 2017. A Simple, efficient and rapid method for good quality DNA extraction from rice grains. Rice Sci. 24(2): 119-122.

Sharma, P., Joshi, N. and Sharma, A. 2010. Isolation of genomic DNA from medicinal plants without liquid nitrogen. Indian J. Exp. Bio. 48: 610614.

Sharma, R., Mahla, H.R., Mohapatra, T., Bhargava, S.C., and Sharma, M.M. 2003. Isolating plant genomic DNA without liquid nitrogen. Plant Mol. Bio. Reporter 21: 43-50.

Sperisen, C. F., Gugerli, Büchler, U. and Mátyás, G. 2000. Comparison of two rapid DNA extraction protocols for gymnosperms for application in population genetic and phylogenetic studies. Genetics 7: 133-136.

Stein, N., Herren, G. and Keller, B. 2001. A new DNA extraction method for highthroughput marker analysis in a large genome species such as Triticum aestivum. Plant Breeding 120: 354-356.

Thomas, J., and Dominic, V.J. 2015. Isolation of high quality DNA from pulverized rice grain samples by tri-phase method. Int. J. Sci. Res. 4(11): 524-527.

Vibhuti, M.J., Viralkumar, B.M. and Vrinda, S.T. 2015. Simple and efficient protocol for RNA and DNA extraction from rice (Oryza sativa L.) for downstream applications. Int.Res.J.Biol. Sci. 4(2):62-67.

\section{How to cite this article:}

Supriya Ambawat, Ram Kumar, Subaran Singh and Rajesh Yadav. 2017. An Easy, Quick and Cost Effective Method of High Quality DNA Extraction from Mungbean [Vigna radiata (L.) Wilczek] Without Liquid Nitrogen. Int.J.Curr.Microbiol.App.Sci. 6(9): 2695-2703. doi: https://doi.org/10.20546/ijcmas.2017.609.332 